\title{
Author Index to Volume 9
}

\begin{tabular}{|c|c|c|c|}
\hline $\begin{array}{lc}\text { Aravot I } & 97 \\
\text { Arefi M } & 103\end{array}$ & $\begin{array}{l}\text { Dave B } 208 \\
\text { de Schiller S } 53\end{array}$ & Larkham PJ 3 & $\begin{array}{l}\text { Sinou M } 61 \\
\text { Steemers K } \quad 61\end{array}$ \\
\hline Batara A 208 & Fraser M 187 & McGlynn S 1 & Turner A 81 \\
\hline $\begin{array}{l}\text { Bishop I } 208 \\
\text { Bjornsson } \mathrm{H} \quad 187\end{array}$ & Grace Wong KM 17 & $\begin{array}{ll}\text { Parin C } & 197 \\
\text { Penn A } & 81\end{array}$ & \\
\hline Bull C 173 & $\begin{array}{lc}\text { Haddad E } & 151 \\
\text { Hayward R } & 1\end{array}$ & Radović D 175 & \\
\hline Childs MC 73 & Hillier B 31 & Reeve A 133 & \\
\hline
\end{tabular}

\section{Keyword Index to Volume 9}

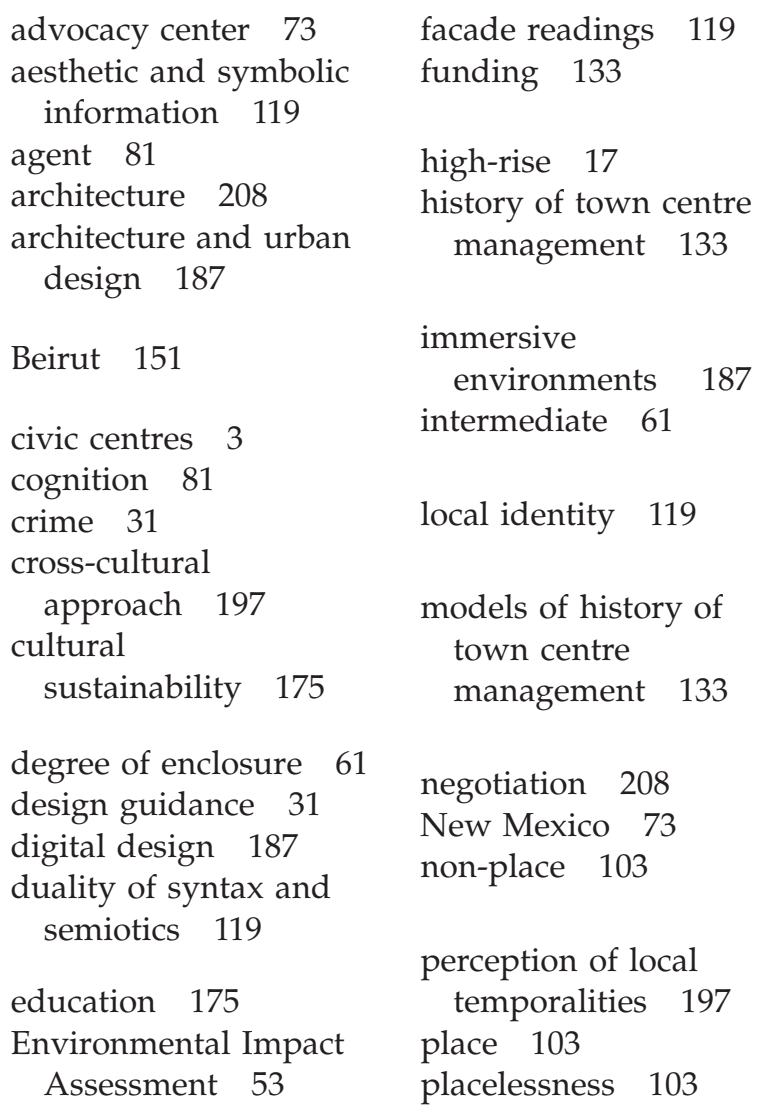

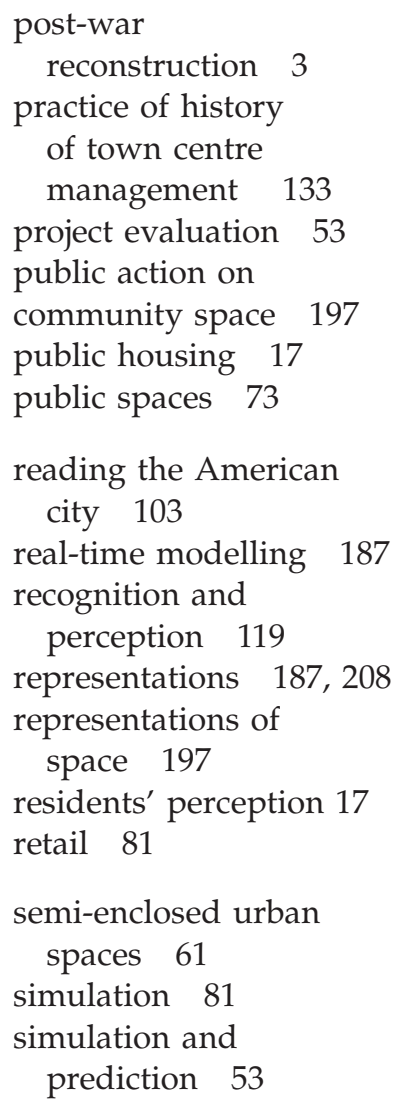

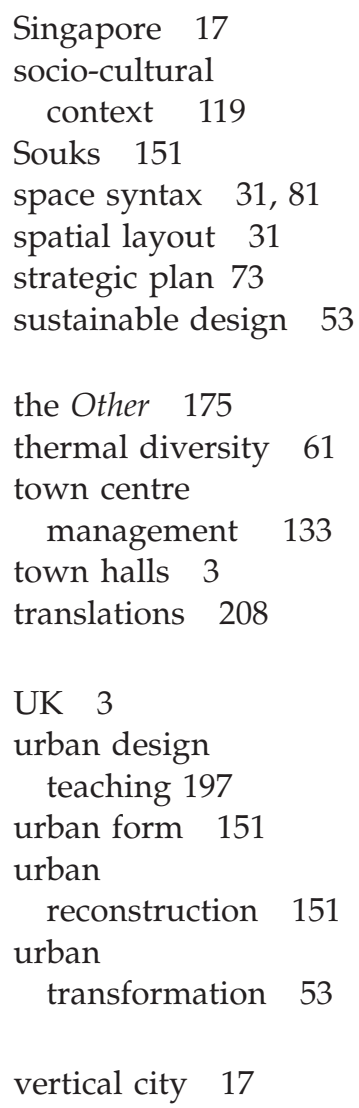

